$\begin{array}{ll} & \text { Etnográfica } \\ \text { etnográfica } & \text { Revista do Centro em Rede de Investigação em }\end{array}$

Antropologia

vol. $20(3) \mid 2016$

Vol. 20 (3)

\title{
Across disciplinary boundaries: remembering Cláudia Sousa
}

Para além das fronteiras disciplinares: lembrando Cláudia Sousa

Margarida Fernandes, Amélia Frazão-Moreira, Kimberley J. Hockings and Francisca Alves-Cardoso

\section{(2) OpenEdition}

\section{Journals}

Electronic version

URL: https://journals.openedition.org/etnografica/4698

DOI: 10.4000/etnografica.4698

ISSN: 2182-2891

\section{Publisher}

Centro em Rede de Investigação em Antropologia

\section{Printed version}

Date of publication: 1 October 2016

Number of pages: $633-640$

ISSN: 0873-6561

\section{Electronic reference}

Margarida Fernandes, Amélia Frazão-Moreira, Kimberley J. Hockings and Francisca Alves-Cardoso,

"Across disciplinary boundaries: remembering Cláudia Sousa", Etnográfica [Online], vol. 20 (3) | 2016 , Online since 27 November 2016, connection on 11 February 2022. URL: http://

journals.openedition.org/etnografica/4698 ; DOI: https://doi.org/10.4000/etnografica.4698

Etnográfica is licensed under a Creative Commons Attribution-NonCommercial 4.0 International License. 


\title{
Across disciplinary boundaries: remembering Cláudia Sousa
}

\section{Margarida Fernandes, Amélia Frazão-Moreira, Kimberley J. Hockings and Francisca Alves-Cardoso}

\begin{abstract}
This dossier pays homage to the primatologist Cláudia Sousa and is the result of a seminar held in her memory. It collates the presentations of Cláudia's colleagues on themes that demonstrate not only the importance of her work but also the legacy that she left. It highlights the potential for novel ways to bring together social and human sciences and biological sciences in the field of anthropology.

KEYWORDS: anthropology, primatology, environment, ethnoecology, conservation, nature, local knowledge.

Para além das fronteiras disciplinares: lembrando Cláudia Sousa - Este dossiê em homenagem à primatóloga Cláudia Sousa resulta do seminário realizado em sua memória e reúne textos apresentados por colegas em torno de temas que ilustram não só a importância do trabalho desenvolvido pela Cláudia mas também o legado que nos deixou e o potencial para desenvolvimentos futuros de aproximação entre as ciências sociais e humanas e as ciências biológicas no campo da antropologia.
\end{abstract}

PALAVRAS-CHAVE: antropologia, primatologia, ambiente, etnoecologia, conservação, natureza, saber local.

FERNANDES, Margarida (m.fernandes@fcsh.unl.pt) - CRIA; Faculdade de Ciências Sociais e Humanas, Universidade Nova de Lisboa (FCSH/Nova), Portugal.

FRAZÃO-MOREIRA, Amélia (amoreira@fcsh.unl.pt) - CRIA; Faculdade de Ciências Sociais e Humanas, Universidade Nova de Lisboa (FCSH/Nova), Portugal.

HOCKINGS, Kimberley J. (hock@fcsh.unl.pt) - CRIA; Faculdade de Ciências Sociais e Humanas, Universidade Nova de Lisboa (FCSH/Nova), Portugal.

ALVES-CARDOSO, Francisca (francicard@fcsh.unl.pt) - CRIA; Faculdade de Ciências Sociais e Humanas, Universidade Nova de Lisboa (FCSH/Nova), Portugal.

\section{CLÁUDIA SOUSA (1975-2014) DEVOTED HER LIFE TO PRIMATOLOGY.} She studied chimpanzee behaviour and cognition in both captive and wild populations and her research contributed to diverse fields including primate conservation, human-primate interactions, and human evolution. Originally trained as a biologist, the breadth of her work surpassed her own area of expertise. Cláudia was capable of conducting fieldwork with the sensitivity and competence of a social scientist, and always maintained that conservation 


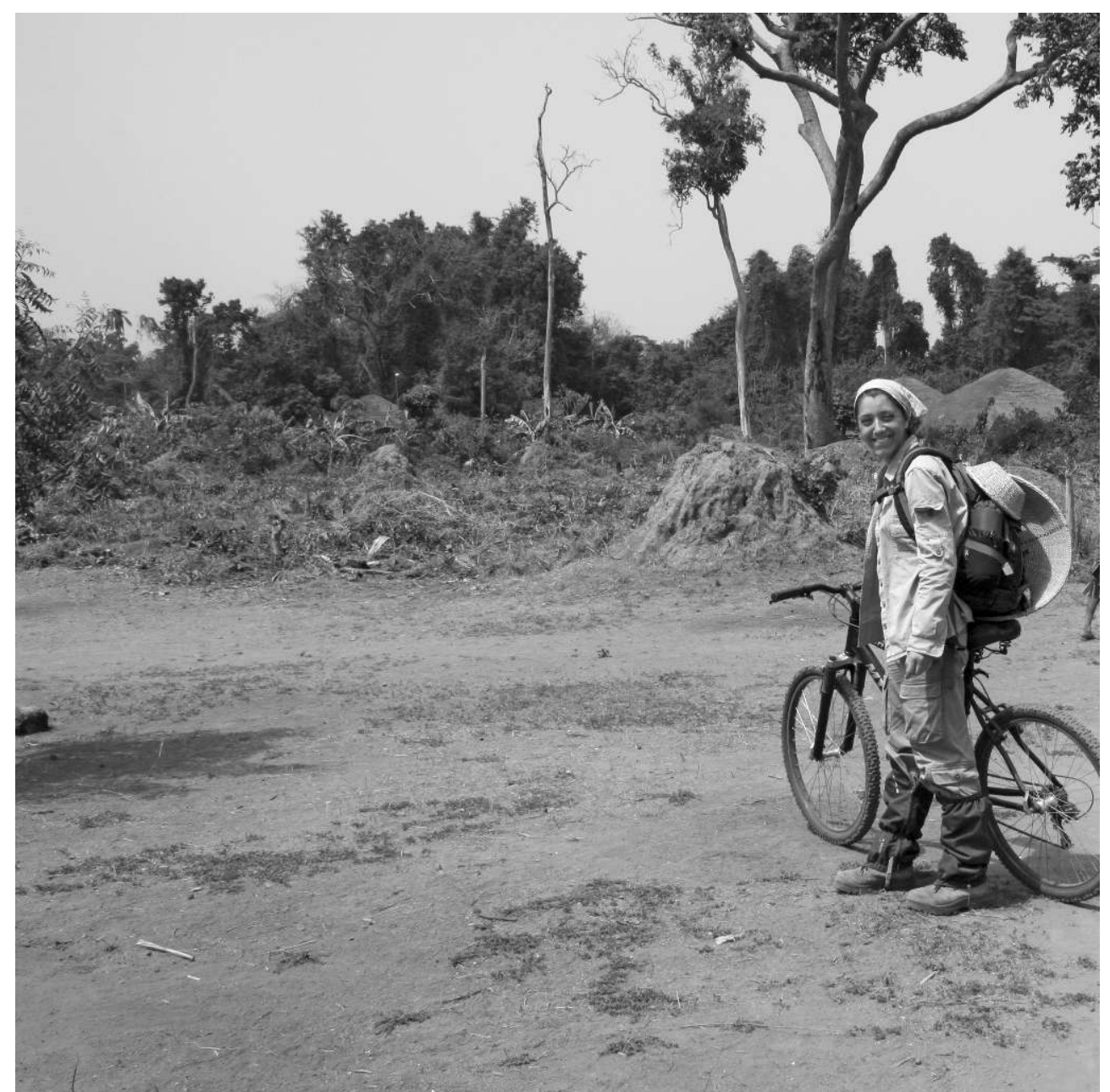

Cláudia enjoying fieldwork at Cantanhez National Park in Guinea-Bissau. 
could not succeed without taking on board the perceptions, knowledge, and interests of local human populations.

The extent of Cláudia's contribution to anthropology was witnessed by everyone who attended the conference held in her memory on the $9^{\text {th }}$ October 2015. ${ }^{1}$ This special dossier of Etnográfica contains extended abstracts of the presentations from this conference and constitutes a further contribution to perpetuate Cláudia's work.

The conference aimed to gather guest speakers who worked with Cláudia, including former mentors and students, and to discuss the issues and research areas that she was passionate about. It was divided into two sections: one dedicated to "Cognition, behaviour and human evolution" and the other to "Conservation and human-primate interactions". These are two major areas of research where Claudia's work had considerable impact in the field of primatology.

Primate cognition is the study of the intellectual and behavioural skills of nonhuman primates (Tomasello and Call 1997). Cognitive abilities evolve to solve the adaptive problems a species faces, with both ecological and social problems important in the evolution of primate intelligence (Byrne and Bates 2006). Great apes in particular are known for their behavioural flexibility, frequent innovation, and high degree of cultural variation (Whiten et al. 1999; McGrew 2004). In the last three decades new theoretical paradigms have been employed to investigate the natural cognitive skills of primates, including complex tool-use (Matsuzawa 2001; Seed and Tomasello 2010). Tool use and manufacture has been reported many times in both wild and captive primates, particularly the great apes. Tool use is an important part of being human and has been central to research into the evolutionary origins of human intelligence. Nonetheless, many basic human cognitive skills are also held by our

1 The conference was organised by FCSH and CRIA and had the financial support of FCT - Fundação para a Ciência e a Tecnologia (Science and Technology Foundation) through the programme FACC - Fundo de Apoio à Comunidade Científica (Scientific Community Support Fund) and the Project CRIA/ANT/04038/2013. The conference was held in the National Museum of Ethnology in Lisbon, Portugal. We would like to express our gratitude to the Museum's Director, Dr. Paulo Costa, and staff, especially Mr. Alexandre Raposo for all their support. A photographic display in the museum entrance provided a visual journey through Cláudia's research career, from her early days working with captive primates in Japan up to more recent research on primate conservation in Guinea-Bissau. Exclusive unedited footage of Cláudia's research work in the laboratory at the Primate Research Institute (PRI, Kyoto University) and in the field at Bossou (Guinea) were shown at the conference and are now available at the Kyoto University webpage which is dedicated to Cláudia's work. The same site provides information on the Cláudia Sousa Memorial Fund for the Advancement of Portuguese Primatology, the aim of which is to give inspiration and encouragement to future generations of Portuguese primatologists. Coinciding with the Conference, the Library services of FCSH/NOVA prepared a display of Cláudia's books which were generously donated by her family. These books, available to students and researchers, are organised in a special collection in the ID - Research and PhD's Documentation Centre (< http://www.fcsh.unl.pt/faculdade/bibliotecas/biblioteca-id >). 
living primate relatives. This is unsurprising considering human and chimpanzee DNA differ by only about $1.23 \%$. However, humans are unique in many ways and display specific cognitive skills that very likely evolved relatively recently in our evolutionary history and that are linked to our cultural way of life.

Tetsuro Matsuzawa and Dora Biro's paper focuses on chimpanzee cognition and more specifically, on flexible tool use. The tools range from "tokens", used as if they were money in a laboratorial context, stones used in the wild to crack nuts, and leaves to gather water. Cláudia's research at the Primate Research Institute (PRI), Kyoto University, Japan, and in the forests of West Africa focused on physical cognition, social learning, laterality and cognitive development. More specifically, it contributed to a better understanding of chimpanzees' ability to think rationally, to find solutions to their problems and learn from their peers. Experiments by Cláudia on chimpanzee use of tokens in social situations are described by Satoshi Hirata. They point to a general social intelligence in chimpanzee daily lives, showing that like humans, chimpanzees have highly sophisticated social skills.

Pursuit for a deeper understanding of tool use by wild chimpanzees sparked the field of primate archaeology. Susana Carvalho introduces the new discipline of primate archaeology highlighting Cláudia's priceless contribution to its foundation. Primate archaeology examines the material record of primates through analyses of tool making, tool use and the spatially patterned accumulation of refuse. Hence it provides an evolutionary framework for understanding primate behaviour. Moreover, "examination of the contexts for nonhuman primate artefact and landscape use, alongside early hominin equivalents, provides a new understanding of the origins and evolution of human behaviour" (Haslam et al. 2009: 339).

Eugénia Cunha's presentation shows that human ancestors were likely capable of compassion - a feeling linked to humanity. ${ }^{2}$ This idea is explored through the analysis of studies reporting evidence of care and attention in the fossil record, such as the willingness and capability to attend individuals with lesions caused by trauma, infection and other impairing pathologies. Cases date back to circa 3.4 million years (Cook et al. 1983) to much more recent examples (Tiley 2015). The author concluded her presentation by suggesting how examining the behaviour of our closest living relatives can contribute to our understanding of the behaviour of our human ancestors (Cuozzo and Sauther 2004; Hublin 2009). The hypothesis presented by Bracinha Vieira

2 On the conference two speakers, unable to attend in person, made video presentations. We are grateful to Catarina Alves Costa (CRIA/FCSH-Nova) and David Navega (University of Coimbra), for directing and editing, respectively, Professor António Bracinha Vieira's and Professor Eugénia Cunha’s video presentations. 
relates to the origins of language and how it is linked with the development of lithic industries in the Palaeolithic. He suggests that brain development and the acquisition of language in humans are associated with the capability to manipulate tools.

This set of contributions highlights the importance of studies into the cognitive abilities of nonhuman primates, especially tool use by chimpanzees, and how this informs various aspects of human evolution, which was a particular focus of Cláudia's research.

The second set of extended abstracts in this dossier focus on great ape conservation. In our current epoch, increasingly known as the Anthropocene (Crutzen and Stoermer 2000; Steffen et al. 2011; Maris 2015), we see the emergence of biodiversity conservation, which some authors argue is important for the survival of humankind (Harmon 2001). However, the extensive (often negative) influence of humans on wild ecosystems where apes are found is undeniable (Hockings et al. 2015). Contemporary biodiversity conservation does not ignore the presence and role of humans in wild ecosystems. Instead it acknowledges that local ecological knowledge and human practices are essential for biodiversity conservation and sustainability (Orlove and Brush 1996; Berkes 1999). Moreover, the value of both biological and human cultural diversity underlines the importance and need to preserve "biocultural diversity" (Maffi 2001; Stepp, Wyndham and Zarger 2002; for a critical review of this process see Vidal and Dias 2016).

The complex relationship between ethnobiology, ethnoecology and conservation (Ellen 2006; Nazarea 2006) will provide new opportunities for intricately examining relationships between human and nonhuman primates using mixed-methods in social anthropology and primatology (ethnoprimatology: Fuentes 2006, 2012; Riley 2006; Sousa and Frazão-Moreira 2010; Fuentes and Hockings 2010). Moreover, a methodological framework that enables the understanding of the ecological complexity based on multispecies ethnography will push this field forward (Kirksey and Helmreich 2010; Malone et al. 2014; Smart 2014).

Kimberley Hockings and Amélia Frazão-Moreira explore these theoretical and methodological advances, whilst showing how Cláudia Sousa pioneered work in the field of human-primate interactions. The paper by Kimberley Hockings on the use of natural and cultivated foods by wild chimpanzees at Caiquene-Cadique in Cantanhez National Park (Guinea-Bissau) shows how this chimpanzee community can flexibly modify their behaviour to changing ecological conditions. She discusses how shared resource use might impact the sustainability of interactions with local people, and ways to promote long-term coexistence in anthropogenic habitats. Amélia Frazão-Moreira explores crossovers in social anthropology and primatology for the conservation of chimpanzees in Cantanhez National Park and Cufada Natural Park, Guinea-Bissau. 
She focuses on the human contexts of conservation, including local narratives and perceptions about chimpanzees; local ecological knowledge and its relation to scientific knowledge; and territory uses and management. She emphasizes the need to connect social variability and the reconfiguration of humanized ecological systems to conservation models and expectations.

Discussions into the connections between social anthropology, primatology and conservation highlight the complex political and ethical dimensions in biodiversity conservation. Catherine Hill and Matthew McLennan reflect upon the ethics of research focusing on "village" chimpanzee behaviour and ecology and discuss the role of the primatologist as a social actor in a complex socio-political landscape. Spartaco Gippoliti maintains the importance of an ethical approach to biodiversity conservation, and highlights the political paradoxes of universalizing conservation models in situ, reinforcing the idea of conservation embedded in local cultures.

Biologists, psychologists and biological anthropologists have played a crucial role in the development of primatology as a scientific discipline. The dialogue between social anthropology and primatology allows us to develop a realistic and holistic understanding of how nonhuman primates fit in an increasingly humanised world. Whether we are discussing the ways in which cognitive studies of nonhuman primates inform human evolution, or the myriad of ways humans interact with nonhuman primates, we are blurring the lines between "cultural" and "natural" approaches, and contributing to important social and biological debates in contemporary anthropology (Ingold and Palsson 2013).

That is the legacy of Cláudia Sousa. 


\section{REFERENCES}

BERKES, Fikret, 1999, Sacred Ecology: Traditional Ecological Knowledge and Resource Management. Philadelphia, Taylor and Francis.

BYRNE, Richard William, and Lucy A. BATES, 2006, "Why are animals cognitive?", Current Biology, 16 (12): R445-R447.

COOK, Della Collins, et al., 1983, "Vertebral pathology in the Afar australopithecines", American Journal of Physical Anthropology, 60: 83-101.

CRUTZEN, Paul, and Eugene STOERMER, 2000, "The 'Anthropocene'”, Global Change Newsletter, 41: 17-18.

CUOZZO, Frank, and Michelle SAUTHER, 2004, "Tooth loss, survival, and resource use in wild ring-tailed lemurs (Lemur catta): implications for inferring conspecific care in fossil hominids", Journal of Human Evolution, 46 (5): 623-631.

ELLEN, Roy, 2006, "Introduction", in Roy Ellen (ed.), Ethnobiology and the Science of Humankind. Malden, MA, Blackwell Publishing, 1-27.

FUENTES, Agustin, 2006, "Human-nonhuman primate interconnections and their relevance to anthropology", Ecological and Environmental Anthropology, 2: 1-11.

FUENTES, Agustin, 2012, "Ethnoprimatology and the anthropology of the human-primate interface", Annual Review of Anthropology, 41: 101-117.

FUENTES, Agustin, and Kimberley Jane HOCKINGS, 2010, “The ethnoprimatological approach in primatology", American Journal of Primatology, 72 (10): 841-847.

HARMON, David, 2001, "On the meaning and moral imperative of diversity", in Luisa Maffi (ed.), On Biocultural Diversity: Linking Language, Knowledge, and the Environment. Washington, DC, Smithsonian Institution Press, 53-70.

HASLAM, Michael, et al., 2009, "Primate Archaeology", Nature, 460: 339-344.

HOCKINGS, Kimberley J., et al., 2015, "Apes in the Anthropocene: flexibility and survival”, Trends in Ecology and Evolution, 30: 215-222.

HUBLIN, Jean-Jacques, 2009, "The prehistory of compassion”, Proceedings of the National Academy of Sciences of the United States of America (PNAS), 106 (16): 6429-6430.

INGOLD, Tim, and Gisli PALSSON, 2013, Biosocial Becomings: Integrating Social and Biological Anthropology. Cambridge, Cambridge University Press.

KIRKSEY, S. EBEN, and Stefan HELMREICH, 2010, “The emergence of multispecies ethnography", Cultural Anthropology, 25 (4): 545-576.

MAFFI, Luisa (ed.), 2001, On Biocultural Diversity: Linking Language, Knowledge, and the Environment. Washington, DC, Smithsonian Institution Press.

MALONE, Nicholas, et al., 2014, "Ethnoprimatology-critical interdisciplinarity", Critique of Anthropology, 34 (1): 8-29.

MARIS, Virginie, 2015, "Back to the Holocene: a conceptual, and possibly practical, return to a nature not intended for humans", in Clive Hamilton, Christophe Bonneuil and François Gemenne (eds.), The Anthropocene and the Global Environmental Crisis: Rethinking Modernity in a New Epoch. London and New York, Routledge, 123-133.

MATSUZAWA, Tetsuro, 2001, Primate Origins of Human Cognition and Behavior. Tokyo, Springer. McGREW, William C. (ed.), 2004, The Cultured Chimpanzee: Reflections on Cultural Primatology. Cambridge, Cambridge University Press.

NAZAREA, Virginia D., 2006, "Local knowledge and memory in biodiversity conservation", Annual Review of Anthropology, 35: 317-335. 
ORLOVE, Ben, and Stephen BRUSH, 1996, "Anthropology and the conservation of biodiversity”, Annual Review of Anthropology, 25: 329-352.

RILEY, Erin, 2006, "Ethnoprimatology: toward reconciliation of biological and cultural anthropology", Ecological and Environmental Anthropology, 2 (2): 75-86.

SEeD, Amanda, and Michael TOMASEllo, 2010, "Primate cognition", Topics in Cognitive Science, 2: 407-419.

SMART, Alan, 2014, "Critical perspectives on multispecies ethnography", Critique of Anthropology, 34 (1): 3-7.

SOUSA, Cláudia, and Amélia FRAZÃO-MOREIRA, 2010, "Etnoprimatologia ao serviço da conservação na Guiné-Bissau: o chimpanzé como exemplo”, in Ângelo Giuseppe Chaves Alves, Francisco José Bezerra Souto and Nivaldo Peroni (eds.), Etnoecologia em Perspectiva: Natureza, Cultura e Conservação. Recife, NUPEEA, 187-200.

STEFFEN, Will, et al., 2011, "The Anthropocene: conceptual and historical perspectives", Philosophical Transactions of the Royal Society of London A: Mathematical, Physical and Engineering Sciences, 369: 842-867.

STEPP, John, Felice WYNDHAM, and Rebecca ZARGER (eds.), 2002, Ethnobiology and Biocultural Diversity. Athens, International Society of Ethnobiology.

TILEY, Lorna, 2015, Theory and Practice in the Bioarchaeology of Care: Bioarchaeology and Social Theory. London, Springer.

TOMASEllo, Michael, and Josep CALL, 1997, Primate Cognition. Oxford, Oxford University Press.

VIDAL, Fernando, and Nélia DIAS, 2016, Endangerment, Biodiversity and Culture. London, Routledge.

WHITEN, Andrew, et al., 1999, “Cultures in chimpanzees”, Nature, 399: 682-685. 